\title{
Child abuse and neglect: ethical issues
}

\author{
Jean Harris Child and Family Psychiatric Service, Dunstable Health Centre, Dunstable
}

\section{Author's abstract}

Children may be abused physically, sexually, emotionally and by omission or commission in any permutation under these headings. This is discussed in terms of the separate and overlapping responsibilities of parents, guardians, the community in which they live and the network of professional services developed to care for, protect and educate children. An attempt is made to place these issues within an ethical framework, with regard to the legislature of England and Wales.

It is argued that professionals working within this field have an obligation either to keep up to date in respect of a large and growing body of research and practice knowledge or to consult 'experts' within the field when making complex and far-reaching decisions on behalf of abused children and their families.

A representative, inevitably incomplete, bibliography is discussed and appended and there is brief reference to the role of expert witnesses concerning children involved in civil legal proceedings.

Work with children at risk of abuse involves four stages. These are recognition, evaluation, immediate protection and future planning. It is arguable that the most important ethical obligation of any professional involved in this work is continuing education in this complicated and fast-developing field. This involves not only an awareness of the child's family, community and culture and of the legal system available to protect the child, but also of a system of specialist resources which includes obstetrics, paediatrics, the psychiatry of childhood, adolescence and adult life, social work, economics, social planning, psychology, moral education and an historical perspective on all these issues.

Obviously, no one person can be an expert, or even minimally educated, in all these fields. Theoretical interdisciplinary discussion and mutual education is possible, though expensive and difficult to maintain, and a number of journals and professional associations

\section{Key words}

Abuse (physical, sexual, emotional); children's rights; confidentiality of legal minors; non-accidental injury; parents' rights; permanency planning. exist to further this end (1-8).

Where action is required, there are pitfalls at every step. The most clear-cut issues arise where a child has been injured, sexually abused or neglected and the results are a matter of proof. Then, it is not only ethically possible, but a matter of obligation and duty for relevant practitioners (rather than theoreticians,) drawing on any or all of the above mentioned fields of knowledge, to come together on his (or her) behalf in order to protect and plan for him (and his siblings). Such plans obviously relate to his immediate health and safety, his well-being if he remains in or is restored to his family and his future with them or elsewhere (9, 10, 11).

Frequently, however, abuse is suspected or unprovable. Such situations may create more, and less easily resolved, anxiety among professionals than do those where the issues are clear cut; and the need for consultation and information sharing is, if anything, greater (12).

If such children are to be protected within guidelines laid down by the Department of Health and Social Security $(13,14)$, it seems unavoidable that a proportion of parents who have not been abusive will be subjected to inquiry. Under such circumstances, the ethical nature of communication between doctors, social workers and others may be questioned and, since, if the system is working properly, some inquiries will prove groundless, it may be claimed retrospectively that these inquiries were unethical.

To avoid this dilemma it seems essential that practitioners should always be aware of it, should satisfy themselves before contributing to a case conference or other inquiry into child abuse that there are reasonable grounds for supposing that a child or children may be at risk and should assure themselves that the parents or guardians of the child know that the inquiry is taking place and why.

'Good enough' parents, whatever their social, economic or cultural background, do not, by definition, abuse their children and are unlikely except in error to be suspected of doing so. However, if an attempt is made to define 'good enough parenting' in more detailed and in more abstract terms, immediate difficulties arise regarding so value-laden a concept (15). 
Parenting 'bad enough' to warrant intervention by the State, is a less difficult concept. Just as it is slightly less problematic to decide when a crime has been committed than to define a good citizen, it is less problematic to decide on behalf of a child that the level of parenting available to him is bad enough to make it appropriate for the State to intervene on his behalf. Under such circumstances, indeed, the State has a duty as well as a right to intervene and at this point we are talking about legal rather than ethical or cultural criteria for intervention. However, ethical issues and unavoidable, if often valuable, (since if it is controlled, it facilitates thought and communication) professional anxiety arise along the path which leads to a decision that an abandoned, neglected or abused child be afforded legal protection by the State.

During this process, irrespective of the nature, extent or provability of abuse, an ethical issue of immediate practical importance, concerning the rights of parents and guardians, may create pitfalls for unwary practitioners.

Where children are a result of a legal marriage, both parents, by definition, are guardians of their children until the latter reach 18 years of age. Parents are able to give or withhold consent to medical procedures until their child is 16 years old (Family Law Reform Act 1969 , section 8). However, in a world of separation, divorce, re-marriage, cohabiting and temporary fosterparenting, not all children with health problems, or children at risk of abuse, present at general practitioner surgeries, hospitals or social services departments in the company of their legal guardians. They may arrive in the company of a non-custodial parent, stepparents, foster parents, cohabitees, or members of the extended family. None of these, however concerned with the child's health or well-being, are legally in a position to consent to medical examination or treatment for that child.

Of course, if the child is at risk of his life or in urgent need of pain-relieving or other medical treatment, any doctor has a duty to proceed whether or not parental consent is available. In all other circumstances, it is a matter of established practice to obtain 'parental consent'. It is possible, however, for an unwary general practitioner, for example, to refer a child, brought to the surgery by a step-parent, for paediatric assessment of alleged abuse, without the knowlege or involvement of the child's legal guardian. A casualty officer has admitted an over-dosing adolescent, brought to hospital by a mother, with whom the girl was on an access visit. Forty-eight hours later, the girl's father, who had custody of the child, discovered his daughter's whereabouts. Of course, the father was not informed by his ex-wife because of a continuing battle between them but the casualty officer, ward nursing staff and admitting physician did not ask the appropriate question which would have led them to discover that they were not dealing with the guardian of a gravely ill child.

When the 'State' has become involved, statutorily or otherwise, in the life of a child who has been abused or $\stackrel{\frac{3}{\mathbb{Q}}}{\varrho}$ is at risk of abuse, ethical and legal obligations continue over time. Children should be maintained in or $\overrightarrow{\bar{D}}$. returned to their families of origin only with adequate $?$ assessment of the risks involved or of the strengths or $\vec{F}$ resources which may be mobilised within the family. $\frac{\text { ? }}{?}$ (See references 16, 17, 18, for a discussion of relevant $\frac{C}{\circ}$ background reading). Professionals with specific tasks $\frac{O}{\bar{c}}$. and limited resources must ask themselves to what $\vec{\nabla}$ extent they are, or can be, responsible for 'abusive' $\varrho$ social and economic conditions and what resources are $\omega$ necessary, effective, appropriate and available to $\vec{O}$ neglectful or abusive parents and how these resources can best be provided (19) and what counts as expert $\vec{\omega}$ evidence relevant to such decisions. Children may be placed in temporary open-ended care in institutions or $\overline{0}$ with substitute families. This is particularly likely to happen where the nettles described above are not $\vec{\omega}$ grasped at all. Social workers representing the legal $\vec{\omega}$ guardians of a child in care may not feel able to take the $\infty$ responsibility of returning that child to his natural 을 parents but equally may not feel 'hard hearted' or 'tough minded' enough to plan an alternative future for $\mathcal{D}$ him. To leave a child in limbo is one form of abuse. Another is to see-saw him in and out of his family with $\frac{\mathbb{D}}{3}$ alternating periods in children's homes or short-term foster homes because professional anxiety fluctuates as does the perception of the child's rights vis-a-vis those $\odot$ of his natural parents. (References 20-24 providega or framework for discussing these issues and are helpeg⿵冂𠃍. in civil hearings about, for example, wardship an disputed adoption.)

Children who grow up in institutions do very badly $(25,26,27)$. Institutions, such as children's homes and $\stackrel{\unrhd}{\complement}$ observation and assessment centres can perform $\overrightarrow{\vec{O}}$ valuable functions. For example, they may offer a 3 breathing space while plans are made on behalf of a child and his family, or a base for older adolescents who? need a bridge between family and community. However, institutions, as managed in our society, $\Phi$ cannot provide substitute parenting for children $\frac{}{3}$ unable to live with their original families $(28,29)$. To pretend otherwise is a form of abuse.

The term 'foster care' covers a range of possible

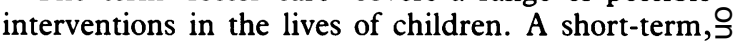
assessment foster home, planned to facilitate close $>$ links between a child and his natural parents, in the hope that they may be re-united as a family, is different $N_{0}$ from a short-term foster home planned as a bridge between a child and a permanent substitute family. A long-term foster home with members of an extended $\omega$ family is different from a two-year agreement between? a social services department and professional fostero parents who are prepared to offer a base to a sixteen-市 year-old until he reaches his majority. Rowe and her ${ }^{\text {? }}$ colleagues $(30,31)$ offer detailed discussion of these $\frac{T}{-}$ issues.

It is a form of abuse to place a child in foster care without working out aims and objectives on his behalfo and clarifying these with his natural family, his foster 
parents and the practitioners responsible for planning the child's future. Research evidence (for example, 3235, reviewed by Harris, 36) indicates that, where work done to retain a child in his family of origin has proved ineffectual, and considered opinion is that a child needs another home, adoption is the least detrimental alternative available to him. Adoption compares favourably with long-term fostering (legal uncertainty militates against successful parenting) and institutional care. This applies even with late adoptions (37). Success is related to the commitment, stability and legal security of the adoptive parents rather than to the child's age, physical disability $(38,39)$ genetic vulnerability (4) or damaging earlier experience (41).

Thus, to return to the starting point and in summary, practitioners in the field of child abuse must recognise and contain, but not deny, their anxiety, must learn and discuss their work and must bear in mind the complex and continuing debate about the rights and duties of parents, the rights and duties of children and the rights and duties of the State. They must also keep in mind the appropriate legal framework for deciding such matters.

If, following abuse, a child is allowed to remain with his parents, restored to them, or taken into the care of the State, risk continues. Plans must be made, risks acknowledged and the decisions taken must be monitored and evaluated over time.

A final form of abuse, to children within a community rather than to a child at risk, is failure to recognise that a body of knowledge exists and is expanding. Research is in need of replication and advancement. Parenting, by individuals or by the State, costs money and effort.

fean Harris FRCPsych is a Consultant (Child and Adolescent Psychiatry) with the North West Thames Regional Health Authority, and an Honorary Consultant to the Royal Free Hospital, London.

\section{References}

(1) Adoption and fostering (quarterly): 11 Southwark Street, London SE1.

(2) British Association for the Study of Child Abuse and Neglect (quarterly): Newsletter. Lincoln House, Corporation Street, St Helens, Lancs.

(3) International journal of child abuse and neglect (quarterly): Headington Hill Hall, Oxford: Pergamon Press.

(4) Childright (monthly): Children's Legal Centre, 20 Compton Terrace, London N1.

(5) Fournal of the Association of Child Psychology and Psychiatry (quarterly): 4 Southampton Row, London WCl.

(6) Fournal of family law (bi-monthly): 15 Pembroke Road, Bristol.

(7) Fournal of the Association for Family Therapy (quarterly): Academic Press, c/o 24-28 Oval Road, London NW1.

(8) Fournal of moral education (quarterly): Social Morality Council, 23 Kensington Square, London W8.

(9) Kempe C H, Helfer R. Helping the battered child and his family. New York: Lippincot, 1972.

(10) Helfer R E, Kempe C H. Child abuse and neglect: the family and the community. Cambridge, Massachusetts: Ballinger, 1976.

(11) Kempe C H, Helfer R E. The battered child (3rd ed) Chicago: University of Chicago, 1980.

(12) Hallett G, Stevenson O. Child abuse: aspects of interprofessional co-operation. London: Allen and Unwin, 1980.

(13) Department of Health and Social Security. Memorandum on non accidental injury to children. Circular LASSL (74) 13 CMO (74) 81974.

(14) Department of Health and Social Security. Emotional abuse of children. Circular LASSL (80) 4HN80 202 2c (ü) 1980.

(15) Adcock M, White R, eds. Good enough parenting. British Agencies for Adoption and Fostering, 11 Southwark Street, London SE1, 1984.

(16) Madge N, ed. Families at risk: studies in deprivation and disadvantage. London: Heinemann Educational, 1982.

(17) Rutter M. Maternal deprivation re-assessed. (2nd ed) Harmondsworth, Middlesex, Penguin, 1982.

(18) Porter R, ed. Child sexual abuse within the family. CIBA Foundation/Tavistock, London, New York CIBA Foundation, 1984.

(19) White-Franklin A, ed. The challenge of child abuse. London, New York: Academic Press, 1977.

(20) Family Rights Group. Fostering parental contact. 6 Manor Gardens, London N7, 1982.

(21) Adcock M, White R. eds. Terminating parental contact. British Agencies for Adoption and Fostering, 11 Southwark Street, London SE1, 1980.

(22) Rawstron D. ed. Children's rights. British Agencies for Adoption and Fostering, 11 Southwark Street, London SE1, 1981.

(23) Parker R A, ed. Caring for separated children. National Children's Bureau, 11 Wakley Street, London ECl, 1980.

(24) Adcock M, White R, Rowlands O. The administrative parent. British Agencies for Adoption and Fostering. 11 Southwark Street, London SE1, 1983.

(25) Wolkind S N, Renton G. Psychiatric disorders in long term residential care: a follow up study. British journal of psychiatry 1979; 135: 129-135.

(26) Wolkind S N, Rutter M. Children who have been 'in care': an epidemiological study. Fournal of child psychology and psychiatry 1973; 14: 97, 105.

(27) Wolkind S N. The components of 'affectionless psychopathy' in institutionalised children. Fournal of child psychology and psychiatry 1974; 15: 215-220.

(28) Tutt N, Chairman. Observation and assessment. Report of a Working Party: Department of Health and Social Security, London, 1981.

(29) Short R, Chairman. Report of the House of Commons standing committee on children in care. London: Her Majesty's Stationery Office, 1984.

(30) Rowe J. Fostering in the eighties. British Agencies for Adoption and Fostering, 11 Southwark Street, London SE1, 1983.

(31) Rowe J, Keane A, Hundleby M, Cain H. Long term foster care. Batsford/British Agencies for Adoption and Fostering, 1984.

(32) Bohman M, Sigvardsson S. Negative social heritage. Adoption and fostering 1980; 3: 25-31.

(33) Clarke A M. Adoption studies and human development. Adoption and fostering 1981; 104, 2: 17-29.

(34) Triseliotis J. Identity and security in long term fostering. Adoption and fostering 1983; 7, 1:22-31. 
(35) Lambert L. Adopted from care by the age of seven. Adoption and fostering 1981; 105, 3: 28-36.

(36) Harris, J. The outcome of adoption. In: Oxtoby M, ed. Taking a stand. British Agencies for Adoption and Fostering, 11 Southwark Street, London SE1, 1984.

(37) Kadushin A. Adopting older children. New York: Colombia University Press, 1970.

(38) Gath A. Mentally retarded children in natural and substitute families. Adoption and fostering 1983; 7, 1:3540.
(39) Wolkind S N, Kozaruk A. The adoption of childre with medical handicap. Adoption and fostering 1983; 7, 1 $32-40$.

(40) Bohman M. The interaction of heredity an\&? environment: some adoption studies. Fournal of chil psychology and psychiatry 1981; 22, 2: 195-200.

(41) Clarke A D P, Clarke A M. Early experience: myth an evidence. London: Open Books, 1976. 